\title{
Articles
}

\section{Development of an Isolable Active Ester, Diethyl Thiophosphoryl [(Z)-(2-Aminothiazol-4-yl)-2-(Methoxyimino)acetate (DAMA) for the Synthesis of Cefotaxime}

\author{
Man-Young Yoon, Hee Bong Lee, and Hyunik Shin* \\ Process Research \& Development, LG Life Science Ltd., R\&D Park, 104-1, Moonji-dong, \\ Yusung-gu, Daejeon 305-380, Korea.*E-mail: hisin@lgls.com \\ Received October 2, 2010, Accepted November 20, 2010
}

\begin{abstract}
An isolable activated ester, diethyl thiophosphoryl [(Z)-(2-aminothiazol-4-yl)-2-(methoxyimino)acetate (9a, DAMA) was prepared in high purity, which was at least stable for $7 \mathrm{~d}$ at $25^{\circ} \mathrm{C}$ and 6 months at $5{ }^{\circ} \mathrm{C}$. Its reaction with 7-ACA (4) in the presence of tributylamine in $i$-PrOH provided cefotaxime (1) of high purity in good yield. Preparation of DAMA and its reaction with 7-ACA (4) to 1 was performed in one-pot manner, respectively with minimal unit operations of stirring and filtration.
\end{abstract}

Key Words: DAMA, Active ester, Cefotaxime, MAEM

\section{Introduction}

As well recognized even in public, the advent of $\beta$-lactam antibiotics marked a distinctive milestone in the pharmaceutical history. After the discovery of penicillin, numerous modifications were followed to result in various $\beta$-lactam antibiotics having enhanced efficacy and broadened spectrum towards bacteria. Among them, cefotaxime (1) ${ }^{1}$ is conspicuous as a thirdgeneration cephalosporin antibiotic, which provides high potency, broad spectrum against Gram positive and negative bacteria, and lowered toxicity profile compared to the predecessors (Figure 1). Later, its analog, the prodrug cefpodoxime proxetil (2) as an orally active cephalosporin ester was marketed by Pharmacia \& Upjohn under the trade name Vantin ${ }^{\circledR}{ }^{2}$

As a general method for the synthesis of cefotaxime, used most frequently ${ }^{3}$ was direct coupling of 7-aminocephalosporanic acid (7-ACA, 4) with $S$-benzothiazol-2-yl(2-amino-4-thiazolyl)(methoxyimino)thioacetate (3a, MAEM) developed by Lonza as illustrated in Scheme 1.
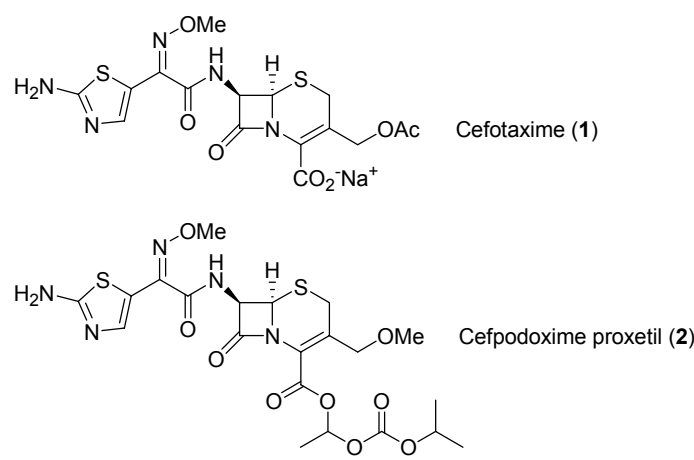

Figure 1. cefotaxime (1) and cefpodoxime proxetil (2).
However, difficult removal of benzothiazole at the end of the reaction motivated researchers to devise alternative active esters such as benzotriazole derivative $\mathbf{3 b},{ }^{4}$ and triphenylphosphine oxide activated form $\mathbf{3 c}$. $^{5}$ However, the first and second approaches are not free from the difficulties experienced with MAEM because tedious and extensive purification is required for the complete removal of hydroxybenzotriazole or triphenylphosphine oxide from the reaction mixture. In addition, they showed low stability to result in limited use due to its difficult handling and transportation as an isolable activated ester.

To overcome these problems, we turned our attention to develop a novel activated ester compound, the activating part of which could be readily removed from the reaction mixture at the end of the reaction by incorporating highly water soluble fragment. Earlier in the development, we investigated the possi-

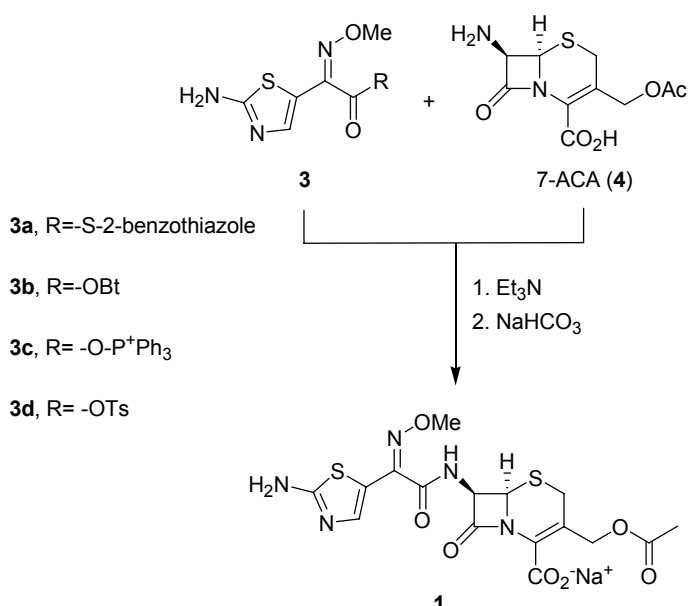

Scheme 1 
Table 1. The synthesis of cefotaxime using phosphoramidate 7 as an activated ester<smiles>[Y]N=C(C)C(=O)OP(=O)(OC)OC(=O)C(=NOC)c1cnc(N)s1</smiles>

\begin{tabular}{|c|c|c|c|c|c|c|}
\hline \multirow{2}{*}{ Entry } & \multicolumn{3}{|c|}{6} & \multicolumn{3}{|c|}{ Results } \\
\hline & & $\mathrm{R}$ & $\mathrm{R}^{1}$ & Active esters $^{a}$ & Purity $^{b}$ & Cefotaxime $(\mathbf{1})^{c}$ \\
\hline 1 & 6a & $\mathrm{CH}_{3}$ & Dimethylamino & $7 a, 65 \%$ & $98.0 \%$ & - \\
\hline 2 & $6 b$ & $\mathrm{CH}_{3}$ & Phenylamino & $7 b, 81 \%$ & $95.0 \%$ & $14 \%$ \\
\hline 3 & $6 c$ & $i$-Pr & Phenylamino & $7 \mathbf{c}, 77 \%$ & $99.0 \%$ & $54 \%$ \\
\hline 4 & 6d & $i$-Pr & 4-Methoxyphenylamino & $7 d, 76 \%$ & $98.0 \%$ & $11 \%$ \\
\hline 5 & $6 e$ & $i$-Pr & 4-Methylphenylamino & $7 e, 65 \%$ & $98.0 \%$ & $9 \%$ \\
\hline
\end{tabular}

$\bar{a}$ isolated yield. ${ }^{b}$ HPLC peak area of $7 .{ }^{c}$ The reaction was stopped when there is no further progress of reaction; it took usually $6-10 \mathrm{~h}$.

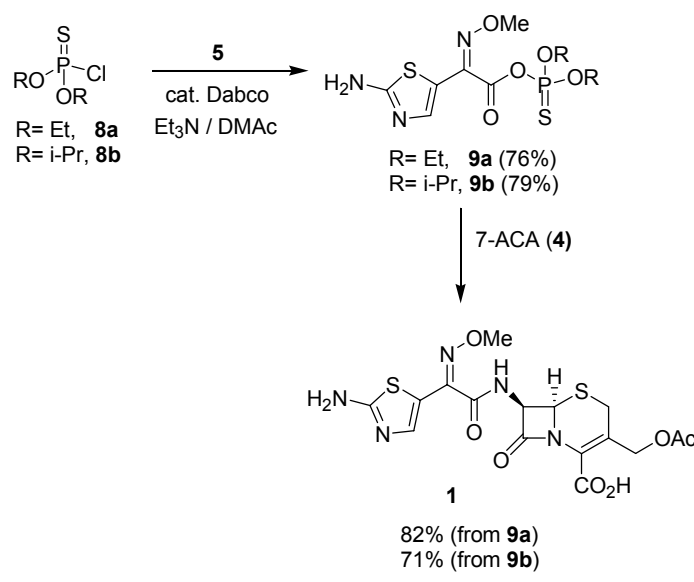

Scheme 2. The synthesis of cefotaxime (1) using thiophosphate ester 9a-b

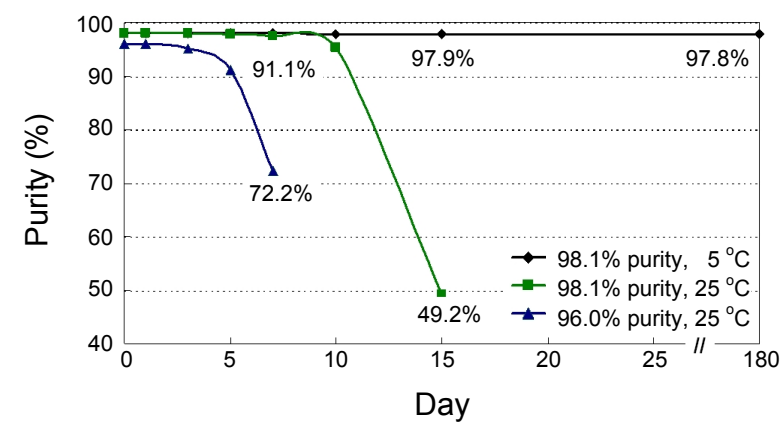

Figure 2. Chemical stability of DAMA (9a)

bility of phosphate ester of (Z)-2-aminothiazol-4-yl)methoxyiminoacetic acid (ATMAA, 5) as its activated ester form. ${ }^{6}$ However, its stability turned out to be insufficient for further development. As an alternative, various phosphoramidates 7 as active esters were prepared and their stability and reactivity were investigated (Table 1). As expected, electron donating amine substituents on the phosphorus atom increased their thermal stability as briefly determined by DSC data. However, coupling reactions of activated esters 7 with 7-ACA (4) provid-
Table 2. The synthesis of DAMA (9a)

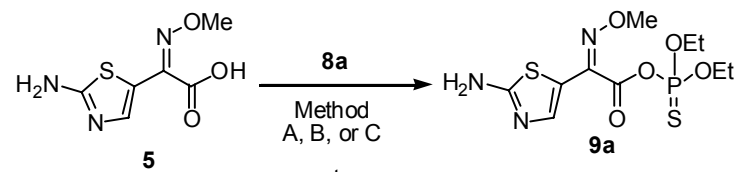

rt

\begin{tabular}{cccc}
\hline Entry & Method $^{a}$ & Purity & Yield $^{b}$ \\
\hline 1 & A & $97.2 \%$ & $79 \%$ \\
2 & B & $98.7 \%$ & $77 \%$ \\
3 & C & $98.8 \%$ & $76 \%$ \\
4 & C & $99.0 \%$ & $78 \%$ \\
$5^{c}$ & C & $99.4 \%$ & $77 \%$
\end{tabular}

${ }^{a}$ Method A: $\mathrm{Et}_{3} \mathrm{~N}$ in DMAc; Method B: $\mathrm{Et}_{3} \mathrm{~N}$ in $i$-PrOH; Method C: $\mathrm{Bu}_{3} \mathrm{~N}$ in $i$-PrOH. ${ }^{b}$ isolated yield as a white solid. ${ }^{c} 450$ mole scale.

ed cefotaxime (1) in low to moderate yield (entries 1-5).

Since it is known that thiophosphate is more stable toward hydrolysis than phosphate, ${ }^{7}$ we shifted our focus to thiophosphate activated esters $\mathbf{9}$, which was readily prepared from the reaction of ATMAA with dialkyl thiophosphoryl chloride (8a and 8b) in DMAc in the presence of triethylamine and catalytic amount of Dabco (Scheme 2). Diisopropyl thiophosphate ester 9b was liquid, which showed very limited stability at room temperature, whereas diethyl thiophosphate ester 9a was isolable as a white solid. However, it showed low stability at ambient temperature as well: 9a of $96 \%$ purity decomposed rapidly after $3 \mathrm{~d}$. Based upon the speculation that the poor stability would be caused by impurities, we prepared highly pure product (assay $>98 \%$ ) by repeated recrystallization, which showed much better stability: it was at least stable for $7 \mathrm{~d}$ at $25{ }^{\circ} \mathrm{C}$ and for 6 months at $5{ }^{\circ} \mathrm{C}$ (Figure 2).

Although highly pure diethyl thiophophoryl (Z)-(2-aminothiazol-4-yl)-2-(methoxyimino) acetate (DAMA, 9a) could be obtained by iterative recrystallization, it is obviously not suitable for large-scale preparation. In this regard, we optimized the process as outlined in Table 2 . We have eventually found that isopropanol is the best reaction solvent in terms of purity and 
Table 3. The synthesis of cefotaxime using DAMA-solvent effect

\begin{tabular}{cccccc}
\hline Entry & Reaction solvent $^{a}$ & $2.0 \mathrm{~N} \mathrm{HCl} \mathrm{in}$ & Purity $^{a}$ & Yield $^{b}$ & Remark (color) $^{c}$ \\
\hline 1 & $\mathrm{CH}_{2} \mathrm{Cl}_{2}: \mathrm{EtOH}=10: 1$ & $\mathrm{CH}_{2} \mathrm{Cl}_{2}: \mathrm{EtOH}=10: 9$ & $96.3 \%$ & $76 \%$ & 0.071 \\
2 & $\mathrm{CH}_{2} \mathrm{Cl}_{2}: i-\mathrm{PrOH}=5: 1$ & $i-\mathrm{PrOH}$ & $95.8 \%$ & $80 \%$ & 0.086 \\
3 & $\mathrm{CH}_{2} \mathrm{Cl}_{2}: i-\mathrm{PrOH}=5: 1$ & $i$-PrOH$: \mathrm{H}_{2} \mathrm{O}=10: 6$ & $98.2 \%$ & $84 \%$ & - \\
$4^{d}$ & $\mathrm{CH}_{2} \mathrm{Cl}_{2}: i-\mathrm{PrOH}=5: 1$ & $i-\mathrm{PrOH}: \mathrm{H}_{2} \mathrm{O}=5: 1$ & $99.2 \%$ & $84 \%$ & 0.062 \\
$5^{e}$ & $\mathrm{CH}_{2} \mathrm{Cl}_{2}: i-\mathrm{PrOH}=5: 1$ & $i-\mathrm{PrOH}: \mathrm{H}_{2} \mathrm{O}=5: 1$ & $97.4 \%$ & $85 \%$ & off-white \\
$6^{f}$ & $\mathrm{CH}_{2} \mathrm{Cl}_{2}: i-\mathrm{PrOH}=5: 1$ & $i-\mathrm{PrOH}: \mathrm{H}_{2} \mathrm{O}=5: 1$ & $99.0 \%$ & $70 \%$ & 0.131 \\
$7^{g}$ & $\mathrm{CH}_{2} \mathrm{Cl}_{2}: i-\mathrm{PrOH}=5: 1$ & $i-\mathrm{PrOH}: \mathrm{H}_{2} \mathrm{O}=5: 1$ & $98.5 \%$ & $76 \%$ & 0.133 \\
$8^{h}$ & $\mathrm{CH}_{2} \mathrm{Cl}_{2}: i-\mathrm{PrOH}=5: 1$ & $i-\mathrm{PrOH}: \mathrm{H}_{2} \mathrm{O}=5: 1$ & $98.6 \%$ & $71 \%$ & 0.098 \\
$9^{i}$ & $\mathrm{CH}_{2} \mathrm{Cl}_{2}: i-\mathrm{PrOH}=5: 1$ & $i-\mathrm{PrOH}: \mathrm{H}_{2} \mathrm{O}=5: 1$ & $98.1 \%$ & $88 \%$ & 0.036 \\
10 & $\mathrm{CH}_{2} \mathrm{Cl}_{2}: i-\mathrm{PrOH}=5: 1$ & $i-\mathrm{PrOH}: \mathrm{H}_{2} \mathrm{O}=10: 1.5$ & $98.3 \%$ & $90 \%$ & 0.014 \\
\hline
\end{tabular}

${ }^{a}$ Volume ratio. ${ }^{b}$ isolated yield. ${ }^{c} \mathrm{UV}$ absorbance at $490 \mathrm{~nm} .{ }^{d}$ use 7-ACA from CKD Pharm corp. ${ }^{e}$ use 7-ACA from CJ corp. ${ }^{f}$ treated with active charcoal. ${ }^{g}$ treated with alumina. ${ }^{h}$ treated with $\mathrm{NaHSO}_{3}$. ${ }^{i}$ treated with $\mathrm{H}_{2} \mathrm{SO}_{3}$.

operational convenience (entry 2). However, we found that use of triethylamine as a base formed its $\mathrm{HCl}$ salt at the end reaction, which was difficult to remove from the 9 a filter cake. Thus, tested were various tert-amines, among which tributylamine was found to be the best: simple washing of the filter cake 9a with $i-\mathrm{PrOH}$ at the end of reaction removed its $\mathrm{HCl}$ salt completely (entry 3 ).

The order of addition is also very critical for the purity and the yield of 9a. When a solution of DETPC (8a) and tributylamine in $i$-PrOH was added to a solution of ATMAA (5) and catalytic amount of Dabco in $i$-PrOH, the yield was $78 \%$ with the assay of $99.0 \%$ (entry 4 ). The reversed addition sequence provided inferior results of the yield in $69-74 \%$ with poorer assay value to the former case. The only side product formed in the reaction was ATMAA isopropyl ester, which was readily removed at the filtration stage. The process was scaled up successfully to a couple of hundred kilogram scale to provide DAMA (9a) in 77\% yield and $99.4 \%$ purity, respectively (entry 5).

Next, the synthesis of cefotaxime (1) was investigated. Earlier in the development, triethylamine was added to the stirred mixture of DAMA (9a) and 7-ACA (4) in $\mathrm{CH}_{2} \mathrm{Cl}_{2} / \mathrm{EtOH}$ (10:1) (entry 1 , Table 3 ). After the completion of the reaction, $\mathrm{HCl}$ in alcoholic solvent was added and crystallization was induced by the addition of seeds. Further optimization of the reaction media (entries 1-4, Table 3) led to find $\mathrm{CH}_{2} \mathrm{Cl}_{2}: i-\mathrm{PrOH}=5: 1$ and $i-\mathrm{PrOH}: \mathrm{H}_{2} \mathrm{O}=5: 1$ as a optimal reaction solvent and as an acidifying solvent, respectively (entries 4-9).

Even under the optimized conditions, the color of cefotaxime was very dependent on the quality of 7-ACA (4) (compare entries 4 and 5): the absorption pattern of cefotaxime at $490 \mathrm{~nm}$ did fluctuate from batch to batch. To assure the consistent control of color impurities in cefotaxime, various additives were tested: active charcoal (entry 6), montmorillonite, and alumina (entry 7) resulted in worsened outcome, whereas the treatment of $\mathrm{NaHSO}_{3}$ led to significant removal of colored material (entry 8). However, residual $\mathrm{SO}_{3}$ and/or $\mathrm{SO}_{4}$ content were pretty high in the final product. To circumvent this issue, $\mathrm{H}_{2} \mathrm{SO}_{3}$ was used, which not only removed the colored material efficiently but also minimized $\mathrm{SO}_{3}$ and/or $\mathrm{SO}_{4}$ content to less than $25 \mathrm{ppm}$ (entries 9-10).

In conclusion, the current cefotaxime (1) synthesis using
DAMA (9a) as an activated ester provides many advantages over the precedents. Preparation of DAMA and its reaction with 7-ACA to cefotaxime (1) were performed virtually in onepot manner with minimal unit operations of stirring and filtration, respectively. Furthermore, cefotaxime (1) was obtained in good yield and high purity.

\section{Experimental Section}

Synthesis of Diethyl Thiophosphoryl (Z)-(2-Aminothiazol4-yl)-2-(methoxyimino) Acetate (DAMA, 9a). To a stirred mixture of diethyl thiophosphoryl chloride $(\mathbf{8 a}, 3.17 \mathrm{~kg}, 1.2$ equiv) and a catalytic amount of Dabco $(5 \mathrm{~mol} \%, 80 \mathrm{~g})$ in $i$ - $\mathrm{PrOH}(10.95 \mathrm{~kg})$ was added portionwise a solution of ATTMA $(\mathbf{5}, 2.82 \mathrm{~kg}, 14.0 \mathrm{~mol})$ and $n-\mathrm{Bu}_{3} \mathrm{~N}(2.85 \mathrm{~kg}, 1.1$ equiv) in $i-\mathrm{PrOH}$ $(10.95 \mathrm{~kg})$ using feeding pump while maintaining the reaction temperature below $25^{\circ} \mathrm{C}$ over $2 \mathrm{~h}$. After $1 \mathrm{~h}, 2.0 \mathrm{~mol} \%$ of DAMA $(\mathbf{9 a}, 0.1 \mathrm{~kg})$ was added as seeds. The reaction mixture was stirred at ambient temperature for $2 \mathrm{~h}$, and then the reaction mixture was cooled to $0-5^{\circ} \mathrm{C}$. The resulting solid was filtered and washed with a mixture of cold $i-\mathrm{PrOH}(15.1 \mathrm{~kg})$, and the filer cake was dried by nitrogen purge to give DAMA ( $3.91 \mathrm{~kg}, 99.4 \%$ assay).

${ }^{1} \mathrm{H} \mathrm{NMR}\left(400 \mathrm{MHz}, \mathrm{CDCl}_{3}\right) \delta 6.80(\mathrm{~s}, 1 \mathrm{H}), 6.02(\mathrm{br} \mathrm{s}, 2 \mathrm{H})$, $4.31(\mathrm{~m}, 4 \mathrm{H}), 3.99(\mathrm{~s}, 3 \mathrm{H}), 1.34(\mathrm{t}, J=7.0 \mathrm{~Hz}, 6 \mathrm{H}) .{ }^{13} \mathrm{C} \mathrm{NMR}$ $\left(100 \mathrm{MHz}, \mathrm{CDCl}_{3}\right) \delta 169.4,157.6\left(\mathrm{~d}, J_{\mathrm{C}-\mathrm{p}}=7.0 \mathrm{~Hz}\right), 145.0(\mathrm{~d}$, $\left.J_{\mathrm{C}-\mathrm{p}}=4.8 \mathrm{~Hz}\right), 141.3,111.6,66.6\left(\mathrm{~d},{ }^{2} J_{\mathrm{C}-\mathrm{p}}=5.6 \mathrm{~Hz}\right), 63.8,16.2$ $\left(\mathrm{d},{ }^{3} J_{\mathrm{C}-\mathrm{p}}=7.0 \mathrm{~Hz}\right)$; MS (ESI): $m / e 354\left([\mathrm{M}+\mathrm{H}]^{+}, 100\right), 186(96)$.

Synthesis of Cefotaxime (1) Free Acid Form. To a stirred solution of DAMA (9a, $42.5 \mathrm{~g}, 1.2$ equiv) and 7-ACA (27.2 g, $100 \mathrm{mmol})$ in a mixture of $\mathrm{CH}_{2} \mathrm{Cl}_{2}(100 \mathrm{~mL})$ and $i-\mathrm{PrOH}(20 \mathrm{~mL})$ was added aqueous $\mathrm{H}_{2} \mathrm{SO}_{3}$ solution $(5.3 \mathrm{~mL}, 5 \mathrm{~mol} \%$ ) at ambient temperature. After stirring for $10 \mathrm{~min}$, triethylamine $(24.8 \mathrm{~g}$, 2.45 equiv) was added dropwise to the resulting mixture maintaining the reaction temperature below $20^{\circ} \mathrm{C}$. After $1.5 \mathrm{~h}$, acidic $\mathrm{HCl}$ solution (15.6 g of conc. $\mathrm{HCl}$ in $i-\mathrm{PrOH}: \mathrm{H}_{2} \mathrm{O}(115 \mathrm{~mL}$, $10: 1.5)$ ) was slowly added to the reaction mixture. When half of the acidic solution was added, cefotaxime seed $(0.46 \mathrm{~g}$, $1.0 \mathrm{~mol} \%$ ) was added. After the complete addition of the residual acidic solution, the mixture was stirred for $1.5 \mathrm{~h}$. The resulting white suspension was filtered and washed twice with $i$-PrOH $(500 \mathrm{~mL})$. Finally, the filter cake was dried by nitrogen 
purge to give cefotaxime (1) free acid form (39.7 g, 86\%) with $99.4 \%$ purity as a white solid.

${ }^{1} \mathrm{H}$ NMR (400 MHz, DMSO- $\left.d_{6}\right) \delta 13.70($ br s, $1 \mathrm{H}), 9.57$ (d, $J=8.4 \mathrm{~Hz}, 1 \mathrm{H}), 7.31$ (s, $2 \mathrm{H}), 6.70(\mathrm{~s}, 1 \mathrm{H}), 5.60$ (m, $1 \mathrm{H}), 5.04$ $(\mathrm{d}, J=4.8 \mathrm{~Hz}, 1 \mathrm{H}), 5.02(\mathrm{~d}, J=12.0 \mathrm{~Hz}, 1 \mathrm{H}), 4.80(\mathrm{~d}, J=12.0$ $\mathrm{Hz}, 1 \mathrm{H}), 3.86(\mathrm{~s}, 3 \mathrm{H}), 3.50$ (d, $J=17.6 \mathrm{~Hz}, 1 \mathrm{H}), 3.25$ (d, $J=$ $17.6 \mathrm{~Hz}, 1 \mathrm{H}), 2.02$ (s, $3 \mathrm{H}) ;{ }^{13} \mathrm{C}$ NMR $\left(100 \mathrm{MHz}, \mathrm{DMSO}-d_{6}\right)$ $\delta 171.4,169.3,165.1,163.9,163.1,149.9,143.4,135.7,113.2$, 109.9, 65.4, 62.8, 58.9, 58.2, 26.2, 21.6; MS (ESI): $m / e ~ 456$ $\left([\mathrm{M}+\mathrm{H}]^{+}, 12\right), 179(156), 101(100)$.

\section{References}

1. (a) Jenkinson, S. G.; Briggs, M. S.; Bryn, R. D. J. Antimicrob. Chemother. 1980, 6, 177. (b) Neu, H. C. Ann. Intern. Med. 1982, 97, 408.

2. Fujimoto, K.; Ishihara, S.; Yanagisawa, H.; Ide, J.; Nakayama, E.; Nakao, H.; Sugawara, S.; Iwata, M. J. Antibiot. 1987, 40, 370.

3. (a) Hitzel, V.; Latrell, D. Chem. Abs. 1979, 92: p22513w. (b) Ro- driguez, J. C.; Hernández, R.; González, M.; López, M. A.; Fini, A. Farmaco 2000, 55, 393. (c) Rodriguez, J. C.; Hernández, R.; Gonalez, Z.; Rodriguez, Z.; Tolon, B.; Velez, H.; Valdes, B.; López, M. A.; Fini, A. Farmaco 2003, 58, 363. (d) Udayampalayam, P. S.; Sivakumaran, S.; Sahoo, P. K. PCT WO 2008041100 , 2008 CAN 148:426634

4. (a) Lim, S. K.; Moon, S. K.; Lee, G. S. EP 175814, 1986; CAN 105: 114832. (b) Koh, D.; Kim, J. H.; Park, S. W.; Kim, Y. Bull. Korean Chem. Soc. 1987, 8, 418. (c) Ohki, H.; Kawbata, K.; Inamoto, Y.; Okuda, S.; Kamimura, T.; Sakane, K. Bioorg. Med. Chem. 1997, 5,1685 .

5. An, S.-H.; Lee, K.-H.; Yun, M.-S.; Kim, Y.-J.; Jang, M.-S. KR 951357, 1995; CAN 133:177061.

6. (a) Lee, H.-W.; Kang, T. W.; Cha, K. H.; Kim, E.-N.; Choi, N. -H.; Kim, J.-W.; Hong, C. I. Synth. Commun. 1998, 28, 35. (b) Kang, T.-W.; Moon, W.-S.; Choi, Y.-W.; Hwang, K.-J. PCT WO 1996012712, 1996; CAN 125:114388. (c) Takeuchi, Y: Yamada, S. Chem. Pharm. Bull. 1974, 22, 832.

7. (a) Zenoni, M.; Leone, M.; Sala, B. IT 1301988, 2000; CAN 137: 154929. (b) Lee, C.-S.; Ryu, E.-J.; Oh, S. H.; Paek, K.-S.; Kim, M. Y.; Youn, H. Bioorg. Med. Chem. Lett. 2000, 10, 2123. 